\title{
EFFECT OF POTASSIUM AND BORN ON GROWTH AND PRODUCTIVITY OF BROAD BEAN IN SANDY SOIL - BALOZA-NORTH SINAI
}

Habib, A.A.M. ${ }^{1}$; F.A.El- Azizy ${ }^{1}$ and A.M. Abd-El baset ${ }^{2}$

${ }^{1}$ Desert Research Center, Soil Fertility and Microbiology Dep.

${ }^{2}$ Desert Research Center, Plant Production Dep.

Key Word: K silicate, K sulphate, Boron, nutrients concentrations and uptake Sandy soil North Sinai.

\section{ABSTRACT}

The experimental field is located at $31^{\circ} 3^{\prime} 0^{\prime \prime} \mathrm{N} 32^{\circ} 36^{\prime} 0^{\prime \prime} \mathrm{E}$. Broad bean crop is cultivated in winter season 2019.The objective of this work was to study the effect of B and $\mathrm{K}$ as foliar application at rates of $50,75 \mathrm{ppm}$ for B while 1000 and 2000 ppm for $\mathrm{K}$ as silicate and $\mathrm{K}$ sulphate on growth and productivity of broad bean grown sandy soil at Baloza station-North Sinai. The obtained results indicated that the yields components of broad bean were improved with increasing B application. The $\mathrm{K}$-forms took the same behavior of $\mathrm{B}$ where the $\mathrm{K} 2$ showed the higher effect on the yield parameters than $\mathrm{K} 1$. The $\mathrm{K}$ silicate had the priority than sulphate. The nutrients concentrations increased with increasing rates of $K$ and the silicate forms gave higher values than sulphate forms. Also N, P, K and B uptake had the same behavior as nutrients concentrations. The most efficient treatment was found where using the second rate of both $\mathrm{B}$ and $\mathrm{K}$ silicate form which achieved 2.92 and 1.11 ton/ fed of shoots and seeds broad bean plants and noticed that highest K- utilization of yields (shoot + seeds) with $\mathrm{K}$ - silicate form addition.

\section{INTRODUCTION}

Faba bean (Vicia faba, L.) is one of the most important leguminous crops used as a human diet in many countries. Sandy soils encourage rapid loss of added fertilizers and hence, they are mostly poor in their nutrient contents.

$\mathrm{B}$ is one of the essential elements for plant growth and productivity, especial importance in retaining flowering and fruit setting. It is leachable in sandy soils. Researches have been done on Boron foliar application near pod setting and seed -filling stages (Zhang, 2001). Shaaban, et al., (2004) reported that the boron deficiency found to affect plant growth and reduced yields. Better growth and good yields were obtained when crops were supplied with boron (Gupta, $1989 \& \mathrm{Li}$ and Liang, 1997). Shaaban and El-Fouly, (2001) reported that boron application increased phosphorus uptake by faba bean roots. Mola, et al., (1998) reported that the $\mathrm{Ca}, \mathrm{B}$ and $\mathrm{K} / \mathrm{Na}$ ratios declined in leaves of faba bean as a response of boron 
application. Boron has a synergetic effect on nitrogen and other nutrients uptake and utilization by faba bean plants, in sandy soil (Mahmoud, et al., 2006).

Potassium is an important nutrient for plant growth and physiological functions, including regulation of water and gas exchange in plants, protein synthesis, enzyme activation, and photosynthesis and carbohydrate translocation in plants. Potassium has favorable effects on metabolism of nucleic acids, proteins, vitamins and growth substances (Bednarz and Oosterhuis, 1999). Wang, et al., (2013) and Salami and Saadat, (2013) pointed out that the K plays an essential roles in enzyme activation, protein synthesis, photosynthesis, osmoregulation, stomata movement, energy transfer, phloem transport, cation-anion balance and stress resistance. The foliar applications of $\mathrm{K}$ can improve yield and quality, especially in heavy clay or in sandy soils where $\mathrm{K}$ is not readily available for the plants (Marchand and Bourrie, 1999). Various sources of K salts are used for plants nutrition such as potassium chloride $(\mathrm{KCl})$, potassium sulphate $\left(\mathrm{K}_{2} \mathrm{SO}_{4}\right)$, mono potassium phosphate $\left(\mathrm{KH}_{2} \mathrm{PO}_{4}\right)$, and potassium nitrate $\left(\mathrm{KNO}_{3}\right)$ (Magen, 2004). Also potassium silicate $\left(\mathrm{K}_{2} \mathrm{O} .4 \mathrm{SiO}_{2}\right)$ caused very good results to improve the growth and yield of plants under saline conditions (Salim, et al., 2011 \& 2013 and Salim, 2014). Sufficient potassium help plants resist frost, drought and certain diseases. Tahir, et al., (2006) reported that potassium has a significant role in improving plant water status and mitigating the toxic effects of $\mathrm{Na}$.

Silicon has not been proven to be an essential element for higher plants, but its beneficial effects on growth have been reported in a wide variety of crops, including rice, wheat, barley and cucumber. Si fertilizer is applied to crops in several countries for increased productivity and sustainable production (Ma, et al., 2001). The amount of Si in soil may vary considerably from $1 \%$ to $45 \%$ (Sommer, et al., 2006). Most Si is present in the soil as insoluble oxides or silicates, but plants can easily absorb silicic acid $\mathrm{Si}(\mathrm{OH})_{4}$ from soil. Silicic acid is generally found in the range of 0.1$0.6 \mathrm{mM}$ in soils (Epstein, $1994 \&$ 1999) The agricultural benefits of silicon amendments on a soil ecosystem are well established. Silicon has been shown to mitigate adverse effects of water, mineral deficiency (Ma, et al., 2001) and alleviate the effects of biotic stresses including salt stress, metal toxicity and nutrient imbalance (Ma, 2004).

Pandey and Yadav, (1999) reported that spraying silicon increased grain yield/plant of wheat. As well as increase in plant water status, chlorophyll content, biological yield and harvest index, coupled with 
reduced values of water potential, increase in dry matter accumulation, dry matter production rate, leaf area/ plant at the flowering stage, productive tillers, grains and grain yield/main spike and per plant and transpiration rate coupled with a decrease in stomata conductance. Silicon application correct to some extent the negative effects of salinity either on growth, yield, nutrients uptake.

Concerning the nutrients effect on other nutrients concentration and uptake, Ati and Ali, (2011) reported that the nitrogen and phosphorus percentage (\%) of dry weight and as uptake by beans increased with increasing rate of boron applications. Hossain, et al., (2011) reported that the effect of B on the nutrient uptake of six elements followed the order K> $\mathrm{N}>\mathrm{S}>\mathrm{P}>\mathrm{B}>\mathrm{Zn}$ and these were significantly influenced by increasing $\mathrm{B}$ application. Khattab, et al., (2016) reported that the spray foliar application of boron (150 ppm), potassium sulphate (2\%) and potassium phosphate $(1.5 \%)$ significantly increased all the studied characters, with superiority the interaction of boron $150 \mathrm{ppm}$ and potassium phosphate $1.5 \%$ which caused the highest increases in all the studied characters. Taha, et al., (2016) decided that the mean values of vegetative growth parameters as (plant height, fresh and dry weight as well as leaf area), fresh weight of pods and seeds of faba bean, N, P, K, Fe in plant foliage and seeds were increased significantly with increasing rates of potassium fertilizers. Siam, et al., (2018) stated that the $\mathrm{N}, \mathrm{P}$ and $\mathrm{K}$ content and uptake by shootss, and grains increased by $\mathrm{Si}$ addition as they compared with those without $\mathrm{Si}$ addition.

Fertilizer efficiency is an objective for all involved in agriculture, the fertilizer industry, and researchers to helping farmers to increase crop yield. This describes between yield, nutrient efficiency, and the environment was soundly suitable by Dibb (2000). The Present investigation aimed to study the effect of Boron (B) as foliar application and some sources of potassium (K) fertilization (sulphate and silicate) and their interaction on yield and yield component as well as the chemical composition of shoots, seeds and their K -utilization efficiency of broad bean plants grown in sandy soil under drip irrigation system at Baloza station at North Sinai.

\section{MATERIAL AND METHODS}

A field experiment was carried out at Baloza Research Station of the Desert Research Center, Egypt, located at 31 $3^{\prime} 0^{\prime \prime} \mathrm{N} 32^{\circ} 36^{\prime} 0^{\prime \prime}$ E. Using Broad bean crop in winter season 2019. The main target is to study the effect of $\mathrm{B}$ and $\mathrm{K}$ as foliar application at rate 50, $75 \mathrm{ppm}$ for B as (Boric acid 17\% B) while 1000 and $2000 \mathrm{ppm}$ for $\mathrm{K}$ as (silicate or sulphate) $\left[\mathrm{K}_{2} \mathrm{SO}_{4}\right.$ (contained $50 \% \mathrm{~K}_{2} \mathrm{O}$ ) or $\mathrm{K}_{2} \mathrm{SiO}_{3}$ (contained $10 \% \mathrm{~K}_{2} \mathrm{O}$ and $25 \% \mathrm{SiO}_{2}$ )] on 
growth and productivity of broad bean grown in sandy soil at Baloza station, North Sinai.

The studied treatments are compared with farmer treatment in the region. The treatments (B) and (K) were added foliarly after $25 \& 50$ and 75 days after sowing (DAS). Broad bean seeds were sown at 1 November, 2018 , in rows spacing $70 \mathrm{~cm} . \mathrm{w}$ and $20 \mathrm{~cm}$ between seeds/hills $(30,000$ plant/fed). All treatments received $30 \mathrm{~kg} \mathrm{P}_{2} \mathrm{O}_{5} / \mathrm{fed}$ as ordinary superphosphate, $75 \mathrm{~kg} \mathrm{~N} / \mathrm{fed}$ as ammonium sulphate $(20.5 \% \mathrm{~N})$ and half douse of potassium sulphate $(25 \% \mathrm{~K} 2 \mathrm{o})$. Compost as organic manure at rate of $20 \mathrm{~m}^{3} /$ fed and $\mathrm{P}$ were added during soil preparation. While nitrogen fertilizer was applied in three equal doses at sowing and after $25 \& 50$ and 75 days from planting.

The experiment was carried out in a split plot design with three replications (Snedecor and Cochran, 1967), where the main factor was the foliar application of $\mathrm{B}$ and sub main was $\mathrm{K}$ sources. The experiment was irrigated using drip irrigation system. Some physical and chemical properties of the studied soil were determined acceding to Page $\boldsymbol{e t}$ al., (1982) and Klute (1986), as recorded in Table (1).

Table (1). Initial status of some physical and chemical properties of the experimental soil

\begin{tabular}{|c|c|c|c|c|c|c|c|c|c|c|}
\hline $\begin{array}{l}\text { Soil depth } \\
\quad \text { (cm) }\end{array}$ & $\begin{array}{l}\text { pH } \\
\text { Soil } \\
\text { past }\end{array}$ & $\begin{array}{l}\text { E. C } \\
\text { dsm }^{-1}\end{array}$ & \multicolumn{4}{|c|}{$\begin{array}{c}\text { Soluble Cations } \\
\text { (me/l) }\end{array}$} & \multicolumn{3}{|c|}{$\begin{array}{c}\text { Soluble Anions } \\
\text { (me/l) }\end{array}$} & $\begin{array}{c}\text { Texture } \\
\text { class }\end{array}$ \\
\hline \multirow{2}{*}{0 - 30} & \multirow{2}{*}{8.04} & \multirow{2}{*}{1.07} & $\mathrm{Ca}^{++}$ & $\mathbf{M g}^{++}$ & $\mathrm{Na}^{+}$ & $\mathbf{K}^{+}$ & $\mathrm{HCO}_{3}{ }^{-}$ & SO4 $^{=}$ & $\mathrm{Cl}^{-}$ & \multirow{2}{*}{ Sandy } \\
\hline & & & 2.24 & 3.17 & 4.66 & 0.64 & 4.13 & 3.18 & 3.40 & \\
\hline \multirow{2}{*}{$\begin{array}{c}\text { Available } \\
\text { nutrients } \\
\text { (ppm) }\end{array}$} & \multicolumn{2}{|c|}{$\mathbf{N}$} & \multicolumn{2}{|c|}{$\mathbf{P}$} & \multicolumn{2}{|c|}{$\mathbf{K}$} & $\mathbf{F e}$ & Mn & $\mathbf{Z n}$ & $\mathrm{Cu}$ \\
\hline & \multicolumn{2}{|c|}{34} & \multicolumn{2}{|c|}{3.2} & \multicolumn{2}{|c|}{46} & 5.52 & 2.18 & 0.97 & 0.28 \\
\hline
\end{tabular}

pH: Acidity E.C.: Electrical conductivity me/l: mille equivalent per liter.

Chemical analysis of the irrigation water was presented in Table (2). It is clear that such water having $\mathrm{pH}$ value of 7.23 , which mean that it enriched with soluble alkaline ions. It is also having EC value of 2.60 $\mathrm{dS} / \mathrm{m}$ and SAR value of 3.06, which mean that, it is suitable for irrigation Ayers and Westcot (1985).

Table (2). Chemical analysis data of the used irrigation water.

\begin{tabular}{|c|c|c|c|c|c|c|c|c|c|c|}
\hline \multirow{2}{*}{ Parameters } & \multirow[t]{2}{*}{ pH } & \multirow{2}{*}{$\begin{array}{c}\text { E.C } \\
\left(\mathbf{d S m}^{-1}\right)\end{array}$} & \multicolumn{4}{|c|}{$\begin{array}{c}\text { Soluble cations } \\
(\mathrm{me} / \mathrm{l})\end{array}$} & \multicolumn{3}{|c|}{ Soluble anions (me/l) } & \multirow[t]{2}{*}{ SAR } \\
\hline & & & $\mathbf{C a}^{++}$ & $\mathbf{M g}^{++}$ & $\mathrm{Na}^{+}$ & $\mathbf{K}^{+}$ & $\mathrm{HCO}_{3}{ }^{-}$ & $\mathrm{Cl}^{-}$ & $\mathrm{SO}_{4}{ }^{=}$ & \\
\hline Values & 7.23 & 2.60 & 13.90 & 0.43 & 8.20 & 3.50 & 6.0 & 15.20 & 4.80 & 3.06 \\
\hline
\end{tabular}

At maturity (150 days after sowing) the plants were harvested. Number of pods per plant, number of seeds per pod, seed yield/ (Fed) and shoots yield (ton/Fed) were determined of the seeds and shoots were ground 
and wet digested using mixture of $\mathrm{H}_{2} \mathrm{SO}_{4}$ and $\mathrm{HClO}_{4}$ as recommended by Peterburgski (1968) and the following chemical analyses were carried out:

- Total nitrogen was determined using Microkjeldahl method, Phosphorus was calorimetrically determined using ascorbic acid and ammonium Molybdate (Jackson, 1958). Potassium was determined by flame Photometric and (B) by atomic absorption spectrophotometry, all were determined according to the methods described by Chapman and Pratt, (1961).

- Protein content was calculated by multiplying the $\mathrm{N}$ concentration with factor 6.25 .

- The equation used for calculating K- utilization efficiency (KUTE) according to Graham, et al., (1992).

- $\quad($ KUTE $)=(\mathrm{kg}$ dry matter $/ \mathrm{kg}$ uptake $)$.

Nitrogen, P, K and B available in soil at the end experiment were determined according to the methods described by Klute (1889).

\section{RESULTS AND DISCUSSION}

\section{Effect of foliar Boron and $K$ on yield components of broad bean:}

Data in table (3) showed that the yield components of broad bean were increased with increased B application. The $\mathrm{K}$-forms took the same behavior where the $\mathrm{K} 2$ showed the higher effect on yield parameters than $\mathrm{K} 1$. The $\mathrm{K}$ silicate showed superior effect on yield components than sulphate. The superior treatment was the $1^{\text {st }}$ rate of $\mathrm{B}$ and the $2^{\text {nd }}$ rate of $\mathrm{K}$ silicate which achieved 2.92 tons seeds per fed. This variation in the yield may be due to the potassium forms. These results agreed with the obtained by Marchand and Bourrie, (1999); Salim et al., (2011); Abou-Baker et al., (2011); Salim, (2014) and Mahmoud et al., (2019).

Also, the increasing effect of potassium silicate may be due to the positive impact of due to its role in improving physical, chemical and biological condition of soil, its direct effect attributed to its metabolic activity in plant growth. Therefore when plants were treated with potassium, chlorophyll contents were increased which enhanced overall photosynthetic activities of plants and thereby yield. These results are in agreement with (Abdo et al., 2001) who reported that the addition of $1 \mathrm{~kg} \mathrm{~K}_{2} \mathrm{O} / \mathrm{fed}$, as foliar spray, to bean plants significantly increased number of pods/plant, weight, seed yield/plant and seed yield/ (Fed). Silicate solutions had the superiority effect compared with sulphate solutions. This may be refer to silicon which promotes the growth of various higher plant species (Zhu $\boldsymbol{e t}$ al., 2004), although there is a plenty supply of sulphate by addition of all commercial fertilizers and rarity of silicate supply. 
Table (3). Effect of treatments on yield parameters at harvesting of broad bean plants

\begin{tabular}{|c|c|c|c|c|c|c|c|c|}
\hline \multirow{2}{*}{$\begin{array}{c}* \mathbf{B} \\
\text { Rates }\end{array}$} & \multirow[t]{2}{*}{ K Forms } & \multirow{2}{*}{$\begin{array}{c}* \mathbf{K} \\
\text { Rates }\end{array}$} & \multicolumn{2}{|c|}{ No. of Plant } & \multicolumn{2}{|c|}{$\begin{array}{c}\text { Weight } \\
\text { (g plant }^{-1} \text { ) }\end{array}$} & \multicolumn{2}{|c|}{$\begin{array}{c}\text { Weight } \\
\text { (ton fed }^{-1)}\end{array}$} \\
\hline & & & Pods & Seeds & Pods & Seeds & Shoots & Seeds \\
\hline \multicolumn{3}{|c|}{ Control } & 1.50 & 1.37 & 9.01 & 7.99 & 0.61 & 0.24 \\
\hline \multirow{4}{*}{ B1 } & \multirow{2}{*}{ Sulphat } & 1 & 3.67 & 3.33 & 21.97 & 19.50 & 1.48 & 0.58 \\
\hline & & 2 & 5.00 & 4.33 & 27.10 & 25.37 & 2.07 & 0.76 \\
\hline & \multirow{2}{*}{ Silicate } & 1 & 4.33 & 3.67 & 27.53 & 25.20 & 1.69 & 0.76 \\
\hline & & 2 & 5.33 & 4.67 & 32.30 & 30.80 & 2.31 & 0.94 \\
\hline \multirow{4}{*}{ B2 } & \multirow{2}{*}{ Sulphat } & 1 & 5.00 & 4.67 & 30.70 & 28.47 & 2.17 & 0.85 \\
\hline & & 2 & 5.67 & 5.33 & 32.40 & 30.64 & 2.38 & 0.91 \\
\hline & \multirow{2}{*}{ Silicate } & 1 & 5.33 & 4.67 & 35.40 & 32.78 & 2.69 & 0.98 \\
\hline & & 2 & 6.33 & 5.00 & 40.27 & 37.17 & 2.92 & 1.11 \\
\hline \multicolumn{3}{|c|}{ Farmer } & 3.33 & 2.67 & $\mathbf{1 7 . 5 3}$ & 12.96 & 1.13 & 0.41 \\
\hline \multicolumn{9}{|c|}{ Means of Treatments } \\
\hline \multirow{2}{*}{\multicolumn{2}{|c|}{ Means of $B$ rates }} & 1 & 4.58 & 4.00 & 27.2 & 25.2 & 1.89 & 0.760 \\
\hline & & 2 & 5.58 & 4.92 & 34.7 & 32.3 & 2.54 & 0.963 \\
\hline \multirow{4}{*}{$\begin{array}{c}\text { Means } \\
\text { of } \mathbf{K}\end{array}$} & \multirow{2}{*}{ Sulphat } & 1 & 4.34 & 4.00 & 26.3 & 24.0 & 1.83 & 0.715 \\
\hline & & 2 & 5.34 & 4.83 & 29.8 & 28.0 & 2.23 & 0.835 \\
\hline & \multirow{2}{*}{ Silicate } & 1 & 4.83 & 4.17 & 31.5 & 29.0 & 2.19 & 0.870 \\
\hline & & 2 & 5.83 & 4.84 & 36.3 & 34.0 & 2.62 & 1.03 \\
\hline \multicolumn{9}{|c|}{$\operatorname{LSD}_{(0.05)}$} \\
\hline \multicolumn{3}{|c|}{ LSD $_{(0.05)}$ Boron } & 0.655 & Ns & 0.618 & 0.748 & 35.7 & 28.5 \\
\hline \multicolumn{3}{|c|}{ K-forms } & Ns & Ns & 0.222 & 0.690 & 7.33 & 22.8 \\
\hline \multicolumn{3}{|l|}{ K-rates } & 0.720 & 0.544 & 0.604 & 0.539 & 9.03 & 18.4 \\
\hline \multicolumn{3}{|c|}{ Boron x K-forms } & 2.54 & Ns & 0.314 & Ns & 10.4 & Ns \\
\hline \multicolumn{3}{|c|}{ Boron x K-rates } & Ns & Ns & 0.854 & 0.762 & 12.8 & 26.0 \\
\hline \multicolumn{3}{|c|}{ K-forms x K-rates } & 1.02 & Ns & 0.854 & Ns & 12.8 & 26.0 \\
\hline \multicolumn{3}{|c|}{ Boron x K-forms x K-rates } & Ns & Ns & 1.21 & 1.08 & Ns & Ns \\
\hline
\end{tabular}

Effect of foliar Boron and $K$ on nutrients concentrations of broad bean

Data in table (4) clearly showed that nutrients concentration were increased with increasing, also rates of both $\mathrm{B}$ and $\mathrm{K}$ silicate forms showed the high effect on nutrients concentrations than sulphate forms. The most efficient treatment was the addition of the $2^{\text {nd }}$ rate of boron and potassium silicate which achieved highest concentrations of nutrients as following 1.34 and $2.58 \%$ of N, 0.17 and $0.31 \%$ of $\mathrm{P}, 1.70$ and $164 \%$ of $\mathrm{K}$ and 18.80 and $24.40 \mathrm{ppm}$ of $\mathrm{B}$ ppm in shoots and seeds respectively. The provirus results are agreed with the obtained by Mola et al., (1998); Shaaban and El-Fouly, (2001); Shaaban et al., (2004); Mahmoud et al., (2006) and Mahmoud et al., (2019). 
Table (4). Effect of treatments on nutrients concentration in shoots and seeds of broad bean plants

\begin{tabular}{|c|c|c|c|c|c|c|c|c|c|c|}
\hline \multirow[b]{2}{*}{$\begin{array}{l}\stackrel{*}{*} \\
\stackrel{*}{\pi} \\
\stackrel{\tilde{E}}{*}\end{array}$} & \multirow[b]{2}{*}{ K Forms } & \multirow[b]{2}{*}{ 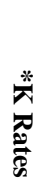 } & \multicolumn{2}{|c|}{$\mathrm{N}(\%)$} & \multicolumn{2}{|c|}{$\mathbf{P}(\%)$} & \multicolumn{2}{|c|}{$\mathbf{K}(\%)$} & \multicolumn{2}{|c|}{ B (ppm) } \\
\hline & & & $\begin{array}{l}\mathscr{2} \\
\bar{\Xi} \\
\ddot{*}\end{array}$ & $\begin{array}{l}\mathscr{\infty} \\
\tilde{\infty} \\
\dot{\infty}\end{array}$ & $\begin{array}{l}\mathscr{2} \\
\stackrel{\Xi}{*}\end{array}$ & $\begin{array}{l}\mathscr{\infty} \\
\tilde{D}^{2}\end{array}$ & 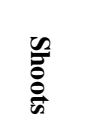 & $\begin{array}{l}\mathscr{\mathscr { D }} \\
\hat{\infty}\end{array}$ & $\begin{array}{l}\mathscr{2} \\
\frac{\tilde{\sigma}}{\ddot{m}}\end{array}$ & 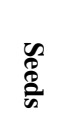 \\
\hline \multicolumn{3}{|c|}{ Control } & 0.34 & 0.86 & 0.06 & 0.09 & 0.56 & 0.46 & 0.23 & 0.34 \\
\hline \multirow{4}{*}{$\bar{\varphi}$} & \multirow{2}{*}{ Sulphat } & 1 & 0.83 & 2.10 & 0.14 & 0.22 & 1.36 & 1.11 & 15.97 & 19.30 \\
\hline & & 2 & 0.87 & 2.13 & 0.14 & 0.23 & 1.43 & 1.21 & 16.40 & 19.73 \\
\hline & \multirow{2}{*}{ Silicate } & 1 & 1.15 & 2.43 & 0.15 & 0.26 & 1.51 & 1.41 & 16.70 & 20.37 \\
\hline & & 2 & 1.17 & 2.49 & 0.16 & 0.26 & 1.56 & 1.48 & 17.87 & 21.07 \\
\hline \multirow{4}{*}{$\hat{n}^{-1}$} & \multirow{2}{*}{ Sulphat } & 1 & 0.93 & 2.24 & 0.15 & 0.24 & 1.46 & 1.31 & 16.93 & 20.70 \\
\hline & & 2 & 1.09 & 2.33 & 0.15 & 0.25 & 1.48 & 1.37 & $\mathbf{1 7 . 6 3}$ & 22.93 \\
\hline & \multirow{2}{*}{ Silicate } & 1 & 1.29 & 2.52 & 0.17 & 0.27 & 1.64 & 1.58 & 18.43 & 21.17 \\
\hline & & 2 & 1.34 & 2.58 & 0.17 & 0.31 & 1.70 & 1.64 & 18.80 & 24.40 \\
\hline \multicolumn{3}{|c|}{ Farmer } & 0.75 & 2.06 & 0.16 & 0.22 & 1.13 & 0.97 & 6.55 & 7.91 \\
\hline \multicolumn{11}{|c|}{ Means of treatments } \\
\hline \multirow{2}{*}{\multicolumn{2}{|c|}{ Means of B Rates }} & 1 & 1.01 & 2.29 & 0.148 & 0.243 & 1.47 & 1.30 & 16.7 & 20.1 \\
\hline & & 2 & 1.16 & 2.42 & 0.160 & 0.268 & 1.57 & 1.48 & 17.9 & 22.3 \\
\hline \multirow{4}{*}{ Means of $\mathbf{K}$} & \multirow{2}{*}{ Sulphat } & 1 & 0.88 & 2.17 & 0.145 & 0.230 & 1.41 & 1.21 & 16.5 & 20.0 \\
\hline & & 2 & 0.98 & 2.23 & 0.145 & 0.240 & 1.46 & 1.29 & 17.0 & 21.3 \\
\hline & \multirow{2}{*}{ Silicate } & 1 & 1.22 & 2.48 & 0.160 & 0.265 & 1.58 & 1.50 & 17.6 & 20.8 \\
\hline & & 2 & 1.26 & 2.54 & 0.165 & 0.285 & 1.63 & 1.56 & 18.3 & 22.7 \\
\hline \multicolumn{11}{|c|}{$\mathbf{L S D}_{(0.05)}$} \\
\hline \multicolumn{3}{|l|}{ Boron } & 0.020 & 0.038 & 0.0024 & 0.0013 & 0.018 & 0.011 & 0.459 & 0.542 \\
\hline \multicolumn{3}{|l|}{ K-forms } & 0.029 & 0.041 & 0.0013 & 0.0028 & 0.019 & 0.011 & 0.362 & 0.406 \\
\hline \multicolumn{3}{|l|}{ K-rates } & 0.012 & 0.016 & 0.0012 & 0.0019 & 0.008 & 0.015 & 0.252 & 0.269 \\
\hline \multicolumn{3}{|c|}{ Boron x K-forms } & Ns & 0.058 & 0.0019 & 0.004 & 0.027 & Ns & Ns & Ns \\
\hline \multicolumn{3}{|c|}{ Boron x K-rates } & 0.017 & Ns & Ns & 0.0026 & 0.012 & Ns & Ns & 0.380 \\
\hline \multicolumn{3}{|c|}{ K-forms x K-rates } & 0.017 & Ns & 0.0017 & 0.0026 & Ns & Ns & Ns & 0.380 \\
\hline \multicolumn{3}{|c|}{ Boron x K-forms x K-rates } & 0.025 & 0.031 & Ns & 0.0037 & 0.017 & Ns & 0.504 & Ns \\
\hline
\end{tabular}

Data presented in Table (5) showed that, effect of foliar application $\mathrm{K}$ form (sulphat and silicate) on K- utilization by dry matter yields (shoot + seeds) in Broad bean plants. As for the effect of $\mathrm{K}$ foliar on kutilization they are found that, highest K-utilization on yields of Broad bean were with $\mathrm{K}$ - silicate form addition high rate and were $62.32 \mathrm{~kg} /$ fed compared with control treatments. And noticed that, low Kutilization with $\mathrm{K}$-sulfate form addition and were $70.98 \mathrm{~kg}$ with low rate of $\mathrm{K}$ sulphate form addition. 
Table (5). Effect of treatments on Potassium utilization in shoots and seeds of broad bean plants.

\begin{tabular}{|c|c|c|c|c|c|}
\hline *B Rates & K Forms & *K Rates & Yield & K Uptake & K Uti. \\
\hline \multicolumn{3}{|c|}{ Control } & 849.70 & 4.52 & 188.04 \\
\hline \multirow{4}{*}{ B1 } & \multirow{2}{*}{ K Sulphate } & 1 & 2061.00 & 26.57 & 77.57 \\
\hline & & 2 & 2834.33 & 38.79 & 73.08 \\
\hline & \multirow{2}{*}{ K Silicate } & 1 & 2446.00 & 36.15 & 67.67 \\
\hline & & 2 & 3250.67 & 49.93 & 65.11 \\
\hline \multirow{4}{*}{ B2 } & \multirow{2}{*}{ K Sulphate } & 1 & 3024.00 & 42.83 & 70.62 \\
\hline & & 2 & $\mathbf{3 2 9 3 . 3 3}$ & 47.82 & 68.88 \\
\hline & \multirow{2}{*}{ K Silicate } & 1 & 3677.00 & 59.80 & 61.49 \\
\hline & & 2 & 4036.33 & 67.81 & 59.52 \\
\hline \multicolumn{3}{|c|}{ Farmer } & 1540.00 & 16.75 & 91.96 \\
\hline \multicolumn{6}{|c|}{ Means of treatments } \\
\hline \multirow{2}{*}{\multicolumn{2}{|c|}{ Means of B Rates }} & 1 & 2648.00 & 37.86 & 70.86 \\
\hline & & 2 & 3507.67 & 54.56 & 65.13 \\
\hline \multirow{4}{*}{ Means of $\mathrm{K}$} & \multirow{2}{*}{ K Sulphate } & 1 & 2542.50 & 34.70 & 74.09 \\
\hline & & 2 & $\mathbf{3 0 6 3 . 8 3}$ & 43.30 & 70.98 \\
\hline & \multirow{2}{*}{ K Silicate } & 1 & 3061.50 & 47.98 & 64.58 \\
\hline & & 2 & 3643.50 & 58.87 & 62.32 \\
\hline
\end{tabular}

Effect of foliar Boron and $\mathrm{K}$ on nutrients uptake $\left(\mathrm{kg} \mathrm{fed}^{-1}\right)$ by broad bean

Data in figures (1- 4) showed the N (Fig. 1), P (Fig. 2), K (Fig. 3) and B (Fig. 4) uptakes. It is noticed the that the effect of the studied treatments indicated the same effect as showed in these concentrations, where increasing application of both B and $\mathrm{K}$ increased the uptake of N, P, K and B. Also, Silicate form indicated the high values compared with sulphate form of K. These results are in agreement with Ati and Ali (2011); Hossain et al., (2011); Khattab et al., (2016); Taha et al., (2016); Siam et al., (2018) and Mahmoud et al., (2019).

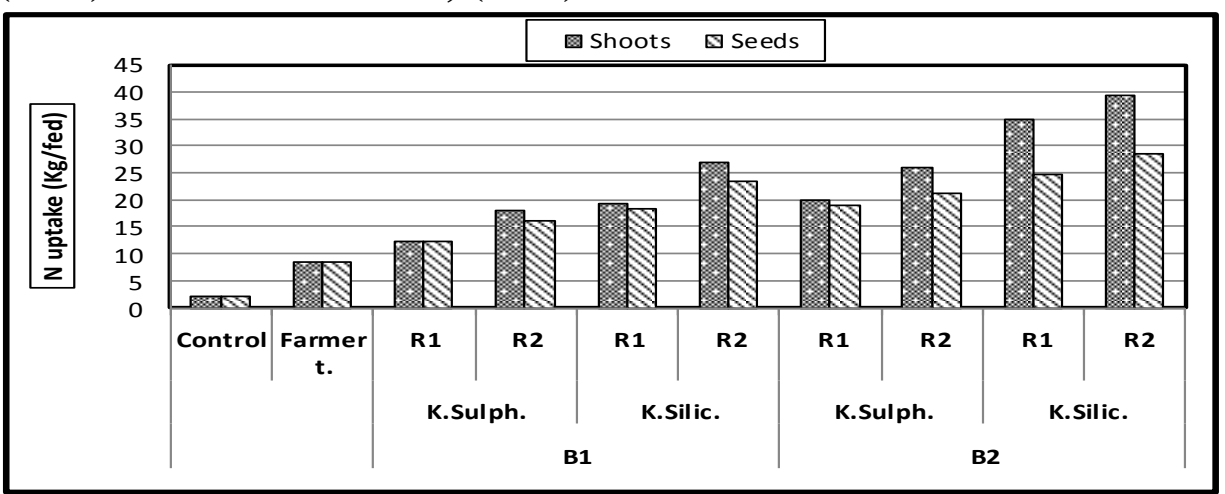

Fig. (1). Effect of treatments on $\mathrm{N}$ uptake in shoots and seeds of broad bean plants. *B Rates as B1, 2= 50, $75 \mathrm{mgL}^{-1}$ or *K Sulphate or Silicate Rates as1, 2= 1000, 2000 ppm. 


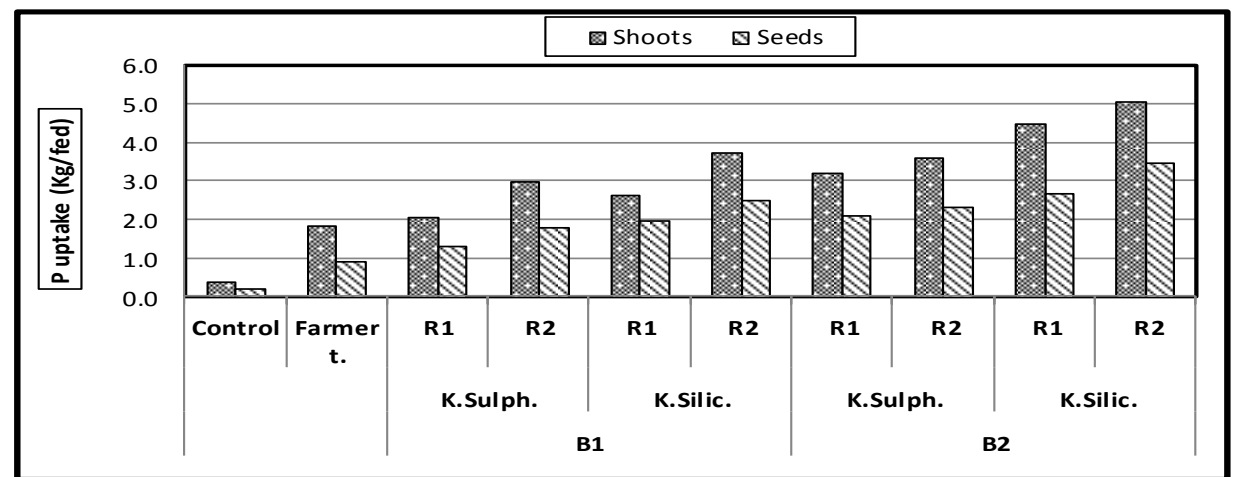

Fig. (2). Effect of treatments on $P$ uptake in shoots and seeds of broad bean plants. *B Rates as B1, 2= 50, $75 \mathrm{mgL}^{-1}$ or *K Sulphate or Silicate Rates as1, 2= 1000, $2000 \mathrm{ppm}$.

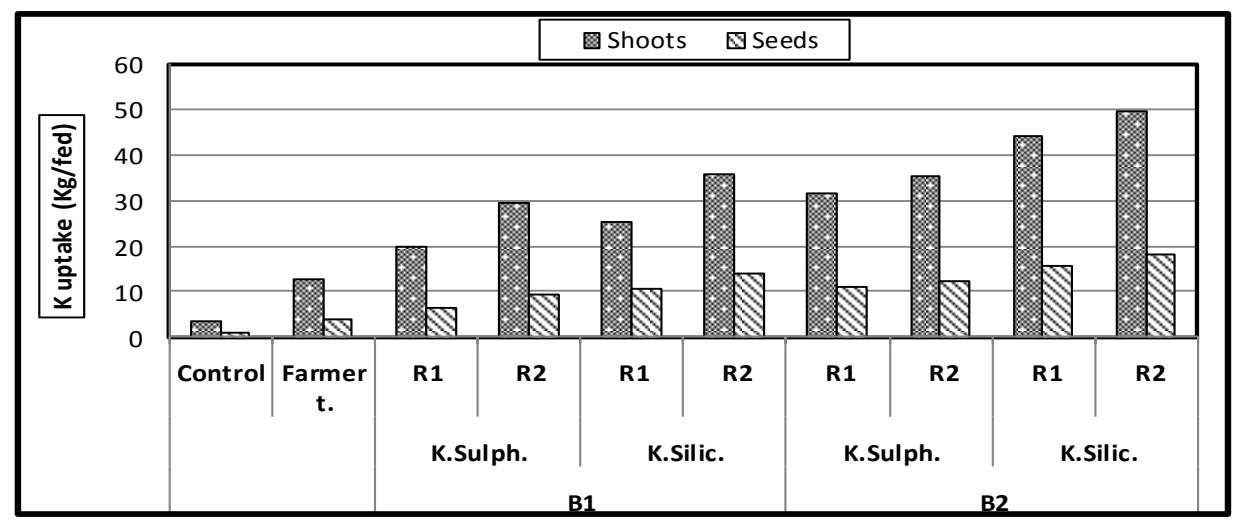

Fig. (3). Effect of treatments on $K$ uptake in shoots and seeds of broad bean plants. *B Rates as B1, 2= 50, $75 \mathrm{mgL}^{-1}$ or *K Sulphate or Silicate Rates as1, 2= 1000, $2000 \mathrm{ppm}$.

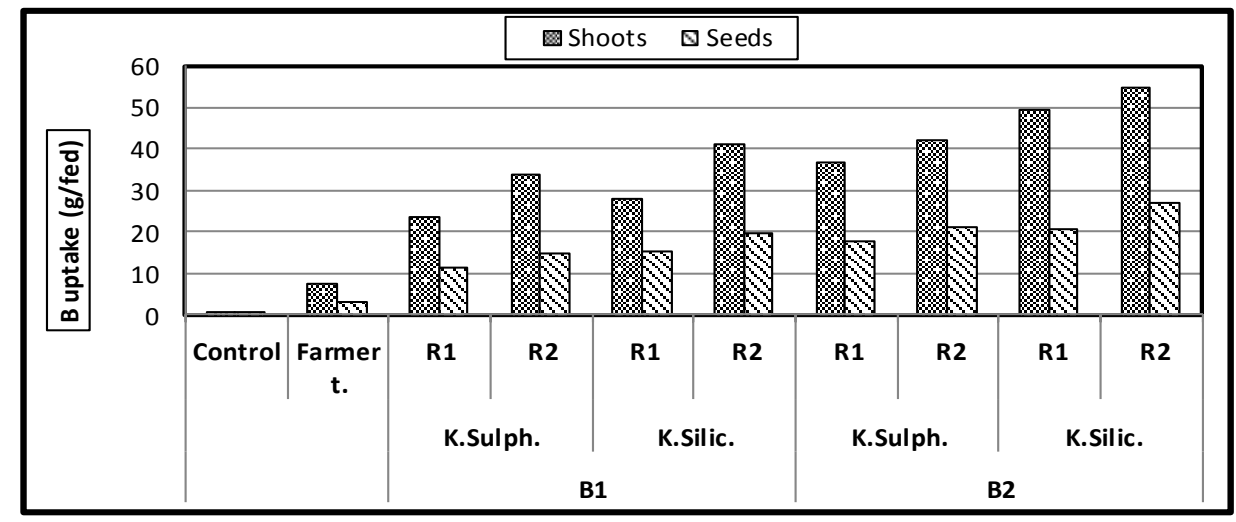

Fig. (4). Effect of treatments on $B$ uptake in shoots and seeds of broad bean plants. *B Rates as B1, 2= 50, $75 \mathrm{mgL}^{-1}$ or $*$ K Sulphate or Silicate Rates as1, 2= 1000, 2000 
Effect of foliar Boron and $K$ on protein content (\%) by broad bean:

At figure (5) it is noticed that bean increased with increasing rates of both B and K. Also, Silicate form of K showed the superior effect compared with sulphate form. Those facts are agreed with the obtained results by Ati and Ali (2011); Hossain et al., (2011); Khattab et al., (2016); Taha et al., (2016) and Siam et al., (2018).

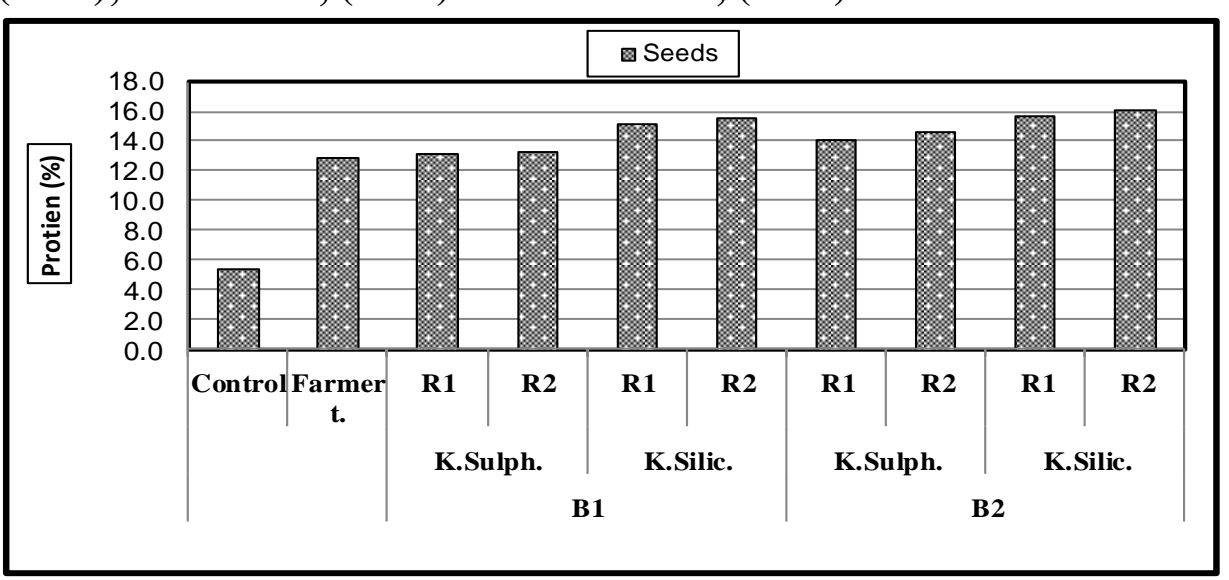

Fig. (5). Effect of treatments on protein content in seeds of broad bean plants. *B Rates as B1, 2= 50, $75 \mathrm{mgL}^{-1}$ or *K Sulphate or Silicate Rates as1, 2= 1000, 2000 ppm.

\section{Mineral content in soil after harvesting:}

The sandy soil had a much lower exchange capacity and concentration of elements such as N, P, K and B than heavier soil. And suffer from loss of elements by leaching. Data in table (6) showed that the studied available elements after harvesting reveal the flowing: Addition of $\mathrm{K}$ fertilization form associated with $\mathrm{B}$ increased the extractable amounts of N, P, K and B this increase of elements in soil after harvesting may be due to $\mathrm{B}$ and $\mathrm{K}$ addition increases nodes of roots hair by Broad bean plants and compost analysis in soil after harvesting. Although, this increase had no arrived to adequate elements of N, P, K and $\mathrm{B}$ in soil after harvesting. The following Tables give an interpretation of the index values for P and $\mathrm{K}$ for the DTPA soil test (Soltanpour et al., 1979); and N by (Jackson, 1958).

\begin{tabular}{||c|c|c|c|}
\hline Category & $\mathbf{P}(\mathrm{mg} / \mathrm{kg})$ & $\mathbf{K}(\mathrm{mg} / \mathrm{kg})$ & $\mathbf{N}(\mathrm{mg} / \mathrm{kg})$ \\
\hline Low & $0->4$ & $0->60$ & $0-40$ \\
\hline Marginal & $4-7$ & $60-120$ & $40->80$ \\
\hline Adequate & $<7$ & $<120$ & $<80-160$ \\
\hline
\end{tabular}

While being the highest extractable amounts of N, P, K and B in soil after harvesting were $40.6 \mathrm{ppm}$ for $\mathrm{N}, 5.4 \mathrm{ppm}$ for $\mathrm{P}$ and $43.4 \mathrm{ppm}$ 
for $\mathrm{K}$ and $0.75 \mathrm{ppm}$ for $\mathrm{B}$ at addition of high level of $\mathrm{B}$ and $\mathrm{K}$ silicate form. It is concluded that plants grown at higher $\mathrm{K}$ level and sufficient $\mathrm{B}$ had better development of nodules and consequently higher nitrogen fixation, it is due to increase of nutrients in the soil after harvesting.

Table (6). Effect of treatments on available N, P, K and B (ppm) after harvesting broad bean plants.

\begin{tabular}{|c|c|c|c|c|c|c|}
\hline \multirow{2}{*}{$\begin{array}{c}\text { B } \\
\text { Rates }\end{array}$} & \multirow{2}{*}{$\begin{array}{c}\mathrm{K} \\
\text { Forms }\end{array}$} & \multirow{2}{*}{$\begin{array}{c}\mathbf{K} \\
\text { Rates }\end{array}$} & $\mathbf{N}$ & $\mathbf{P}$ & $\mathbf{K}$ & B \\
\hline & & & \multicolumn{4}{|c|}{ (ppm) } \\
\hline \multicolumn{3}{|c|}{ Control } & 12.4 & 1.1 & 14.4 & 0.11 \\
\hline \multirow{4}{*}{$\bar{\theta}$} & \multirow{2}{*}{ Sulphat } & 1 & 35.4 & 3.2 & 41.2 & 0.62 \\
\hline & & 2 & 35.8 & 3.7 & 41.3 & 0.64 \\
\hline & \multirow{2}{*}{ Silicate } & 1 & 36.3 & 4.3 & 42.4 & 0.69 \\
\hline & & 2 & 37.1 & 4.5 & 42.7 & 0.71 \\
\hline \multirow{4}{*}{ ص } & \multirow{2}{*}{ Sulphat } & 1 & 36.2 & 3.5 & 41.5 & 0.66 \\
\hline & & 2 & 36.7 & 4.2 & 41.6 & 0.67 \\
\hline & \multirow{2}{*}{ Silicate } & 1 & 38.2 & 4.8 & 43.1 & 0.74 \\
\hline & & 2 & 40.6 & 5.4 & 43.4 & 0.75 \\
\hline \multicolumn{3}{|c|}{ Farmer } & 24.8 & 3.3 & 26.5 & $\mathbf{0 . 5 1}$ \\
\hline \multicolumn{7}{|c|}{$\mathbf{L S D}_{(0.05)}$} \\
\hline \multicolumn{3}{|c|}{$\left.\operatorname{LSD}_{(0.05}\right)$ Boron } & 0.37 & 0.043 & 0.61 & 0.021 \\
\hline \multicolumn{3}{|c|}{ K-forms } & 0.49 & 0.112 & 0.55 & 0.010 \\
\hline \multicolumn{3}{|c|}{ K-rates } & 0.66 & 0.077 & 0.81 & 0.011 \\
\hline \multicolumn{3}{|c|}{ Boron x K-forms } & 0.20 & 0.047 & 0.23 & 0.004 \\
\hline \multicolumn{3}{|c|}{ Boron x K-rates } & 0.91 & 0.106 & 1.13 & 0.014 \\
\hline \multicolumn{3}{|c|}{ K-forms x K-rates } & 0.93 & 0.108 & 1.14 & 0.016 \\
\hline \multicolumn{3}{|c|}{ Boron x K-forms x K- rates } & 0.90 & 0.104 & 1.10 & 0.015 \\
\hline
\end{tabular}

\section{CONCLUSION}

The aim of work is studding the effect of $\mathrm{B}$ and $\mathrm{K}$ as foliar application $\mathrm{K}$ silicate or $\mathrm{K}$ sulphate on growth and productivity of broad bean grown in sandy soil at Baloza station, North Sinai. The yield parameters were increased with $\mathrm{B}$ increasing application. The $\mathrm{K}$-forms took the same behavior in the rates where the K2 showed higher effect on yield parameters than $\mathrm{K} 1$. The $\mathrm{K}$ silicate showed the superior of effect on yield parameters than sulphate. The nutrients concentrations and uptake increased with increasing rates of $\mathrm{K}$ and the silicate forms give the better results than sulphate forms. The most efficient treatment was $\mathrm{B}_{2} \mathrm{~K}_{2}$ as silicate which achieved 2.92 ton seeds fed of bean broad.

\section{REFERENCES}

Abdo, Fatma A. R.H. ; Fardoas and Wafaa M. Rizk (2001). Effect of potassium fertilization on Mung bean (vigna radiate L.) Wilczek, Egypt. J. Appl. Sci., 16(11): 156-167.

Abou-Baker, Nesreen H.; M. Abd-Eladl and M.M. Abbas (2011). Use of Silicate and Different Cultivation Practices in Alleviating Salt 
Stress Effect on Bean Plants. Australian J. of Basic and Applied Sci., 5(9): 769-781.

Ati, A.S. and N.S. Ali (2011). The Effect of Boron Fertilization on Faba bean (Vicia faba L) yield, fertilizer and water productivity. Researches of the First International Conference (Babylon and Razi Universities).1-6.

Ayers, R.S. and D.W. Westcot (1985) Water quality for agriculture. Food and agriculture organization of the United Nations Rome, 1985 (C) FAO. 29 Rev.

Bednarz, C.W. and D.M. Oosterhuis (1999). Physiological changes associated with potassium deficiency in cotton. J. Plant Nutr., 22: 303-313.

Chapman, H.D. and F. Pratt (1961).Methods of Analysis for soils, plants and waters".Dept. of soil. PI. Nutrition, Univ. of California, Davis, U.S.A. 141: 17-23.

Dibb, D.W. (2000) .The mysteries of nutrient use efficiency .Better crops.84:3-5.

Epstein, E. (1994). The anomaly of silicon in plant biology. Proceedings of the National Academy of science, USA, 91: 11-17

Epstein, E. (1999). Silicon, Annual Review of Plant Physiology and Plant Molecular Biology., 50: 641-664

Graham, R.D. ; J.S. Asher and S.C. Hynes (1992). Selecting Zincefficiency cereal genotype for soil of low zinc status. Plant and Soil., 146:241-250.

Gupta, M. (1989). Growth and yield in (Vicia faba L.) in relation to minerals spray. Indian J. Applied Pure Biol., 4: 179-183.

Hossain, M.A.; M. Jahiruddin and F. Khatun (2011). Effect of Boron on Yield and Mineral Nutrition of Mustard (Brassica napus). Bangladesh J. Agril. Res., 36(1): 63-73.

Jackson, M.L. (1958). Soil Chemical Analysis. Prentice-Hall Inc., Englewood Cliff., New Jersey

Khattab, E.A.; Elham A. Badr and M.H. Afifi (2016). Response of Some Varieties of Faba bean (Vicia faba L.) to Boron and Potassium. Inter. J. of Chem. Tech. Res., 9(8): 98-103,

Klute, A.A. (1889)." Method of Soil Analysis ". Part 1,2 $2^{\text {nd }}$ ed., American society of Agronomy .Inc publisher Madison Wisconsin.USA.

Li, Y. and H. Liang (1997). Soil Boron Content and the Effects of Boron Application on Yields of Maize, Soybean, Rice and Sugar Beet in Heilonjian Province, P.R. China. In: Boron in Soils and 
Plants, Beli, R.W. and B. Rerkasem (Eds.). Kluwer Academic Publishers, the Netherlands, pp: 17-21.

Ma, J.F. (2004). Role of silicon in enhancing the resistance of plants to biotic and abiotic stresses. Soil Sci. and Plant Nutr., 50: 11-18

Ma, J.F. ; Y. Miyake and E. Takahashi (2001). Silicon as a beneficial element for crop plants. In: Silicon in Agriculture. (Eds.): Datnoff LE, Snyder GH and Korndorfer GH, Elsevier Sci. B.V., New York, USA.

Magen, H. (2004). Potassium in fertigation systems, International Potash Institute (IPI), 5th Fertigation Training Course, Boading, AUH.

Mahmoud, M.S.; A.F. El-Sayed ; A.E. El-Zanty ; H.M.A. El-Saayed and M. Abdel Kareem (2006). Boron / Nitrogen interaction effect on growth and yield of Faba Bean plants grown under sandy soil condition .International J. Agric Res., 1:322-330.

Mahmoud, S. H. ; Dina M.; Salama ; A.M.M. El-Tanahy and A.M. El-Bassiony (2019). Effects of Prolonged Restriction in Water Supply and Spraying with Potassium Silicate on Growth and Productivity of Potato. Plant Archives., 19 (2): 2585-2595.

Marchand, M. and B. Bourrié (1999). Use of potash fertilizers through different application methods for high yield and quality crops. Developments in Plant and Soil Sci., 86(1): 13-17.

Mola, D.Y.; K.S. Datta; A. Rajiv; D. Jai ; K. Promila and et al., (1998). Mineral ion uptake characteristics during boron toxicity under saline conditions in broad bean (Vicia faba L.). Plant Physiol. Biochem. New Delhi, 25: 114-121.

Page, A.L. ; R.H. Miller and D.R. Keeney (1982).Methods of soil analysis. No. (9), Part 2. Chemical and Microbiological Properties. Ame. Soc., Agron., Inc. Soil. Sci., Mad., Wisc., USA.

Pandey, A.K. and R.S. Yadav (1999). Effect of antitranspirants on phonological traits and yield of wheat under deficit conditions. Indian J. of Agric. Res., 33: 159-164

Peterburgski, A.V. (1968)."Hand Book of Agronomic chemistry "Kolos publishing House ,Moscow. (In Russian). PP. 29-86.

Salami, M. and S. Saadat (2013). Study of potassium and nitrogen fertilizer levels on the yield of sugar beet in jolge cultivar. J. of Novel Applied Sci., 2(4):94-100.

Salim, B.B.M. ( 2014). Effect of boron and silicon on alleviating salt stress in maize. Middle East J. of Agric. Research, 3(4): 1196 -1204. 
Salim, B.B.M.; S.S. Eisa; I.S. Ibrahim; M.G.Z. Girgis and M. AbdRasoul (2011). Enhanced salt tolerance of Wheat Plant. J. Biol. Chem. Environ. Sci., 6 (4): 30-52.

Salim, B. B.M.; S.S. Eisa ; I.S. Ibrahim; M.G.Z. Girgis and M. Abdel-Rassoul (2013). Effect of biofertilizers, mycorrhiza and foliar spraying of some micronutrients $(\mathrm{Fe}+\mathrm{Mn}+\mathrm{Zn})$ and potassium. International Journal of Environment., 2(2): 35-45.

Shaaban, M.M. and M.M. El-Fouly (2001). Boron foliar application improves zinc and other nutrient status in cotton plants grown under low or high calcium carbonate level in the soil. Proceedings of the International Workshop, "Boron 2001" Bonn, Germany June: 23-28.

Shaaban, M.M.; M.M. El-Fouly and A.W.A. Abdel-Maguid (2004). Zinc-boron relationship in wheat plants grown under low or high levels of calcium carbonate in the soil. Pak. J. Biol. Sci., 7: 633-639.

Siam, Hanan S.; M.R. Abd El-Moez ; Sh. Sh. Holah and S.T. Abou Zeid (2018). Effect of silicon addition to different fertilizer on yield of rice (Oryza sativa L.) plants. I- Macro Nutrients by Different Rice Parts. Middle East J. of Applied Sci., 08: 177-190.

Snedecor, G.W. and W.G. Cochran (1967). Statistical methods. 6th ed. silicate on enhancing salt tolerance of wheat plant. International J. of Enviro., 2(2): 35-45.

Soltanpour, N.P. ; A.E. Ludwic and J.O. Reuss (1979). Guide to fertilizer recommendation in Colorado ,45pp.

Sommer, M.; D. Kaczorek; Y. Kuzyakov and J. Breuer (2006). Silicon pools and fluxes in soils and landscapes - a review. Journal of Plant Nutr. and Soil Sci., 169: 310-329.

Taha, A.A.; M.M. Omar and Hadeer R. Khedr (2016). Effect of Different Sources and Levels of Potassium on Growth, Yield and Chemical Composition of Faba Bean. Plants. J. Soil Sci. and Agric. Eng., Mansoura Univ., 7 (3): 243 - 248.

Tahir, M.; A. Rahmatullah; T. Aziz; M. Ashraf; S. Kanwal and M.A. Maqsood (2006). Beneficial Effects of Silicon in Wheat (Triticum Aestivum L.) Under Salinity Stress. Pakistan Journal of Botany, 38(5): 1715-1722.

Wang, M.; Q. Zheng; Q. Shen and S. Guo (2013). The critical role of potassium in plant stress response. International J. of Molecular Sci., 14(4):7370-7390. 
Zhang, L. (2001) .Effects of foliar application of boron and Dimilin on soybean yield. Research report, 22 (16):1-5.

Zhu, Z.; G. Wei ; J. Li ; Q. Qian and J. Yu (2004). Silicon alleviates salt stress and increases antioxidant enzymes activity in leaves of salt-stressed cucumber (Cucumis sativus L.). Plant Sci., 167: 527-533.

تاثير البوتاسيوم والبورون على نمو وانتاجية الفول الرومى بالاراضى الرملية -

$$
\text { بالوظة - شمال سيناء }
$$

اشرف احمد محمد حبيب، ف فتحى عبدالفتاح العزيزى 1، اشرف محمد عبداءلباسط2

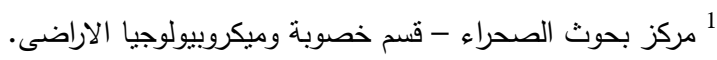

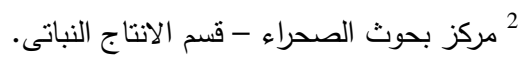

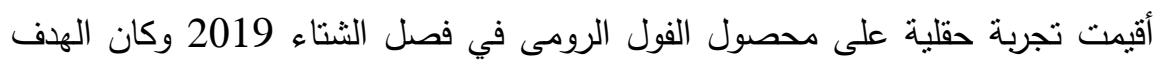

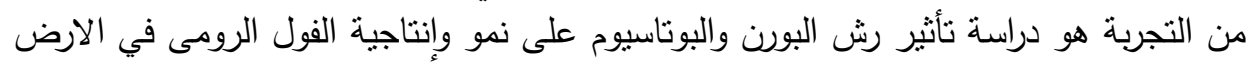

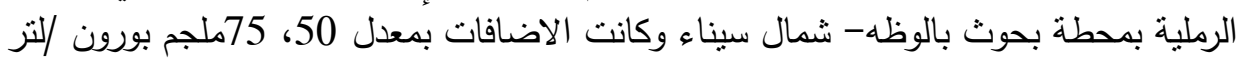

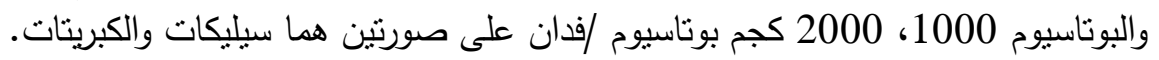

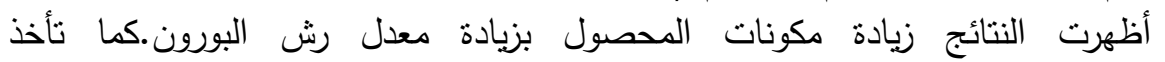

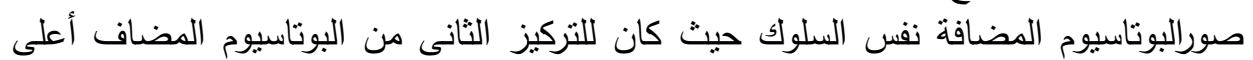

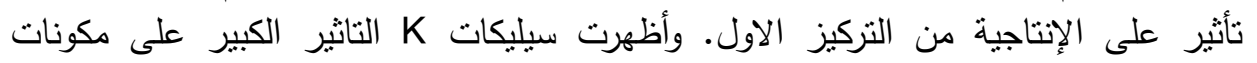

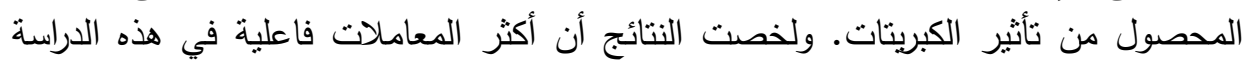

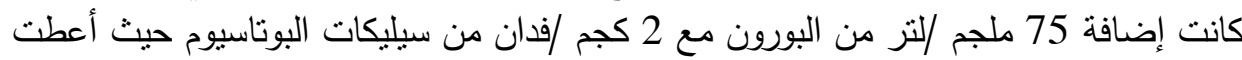

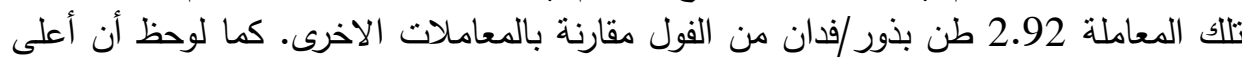

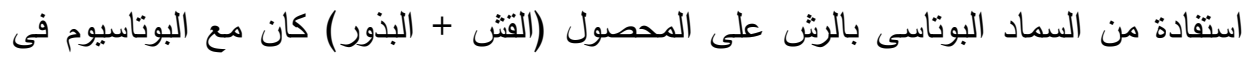

